\title{
The Effect of Leverage, Liquidity, Profitability, Coverage, Growth, and Firm Size With Auditor's Reputation As A Moderating To Bond Rating of Banking Firm
}

\author{
VEGA M. ROSA ${ }^{1}$, MUSDHOLIFAH $^{1}$ \\ ${ }^{1}$ Department of Management, Faculty of Economics, Universitas Negeri Surabaya, Surabaya 60231, Indonesia \\ Email correspondence: musdholifah@yahoo.com
}

\begin{abstract}
This research aims to determine the effect of leverage, liquidity, profitability, coverage, and firm size with auditor's reputation as a moderating to bond rating of banking firm which listed in Indonesia Stock Exchange (BEI) and rated by PT Pefindo period 2004 to 2013. In this research the sample were 176 bond which issued by banking firms. The sampling technique is using purposive sampling method, whereas the method of analysis used logistic regression analysis. This research shows that profitability, growth, and firm size have an effect on bond rating. In the other hand, leverage, liquidity, and coverage have no effect on bond rating. Meanwhile auditor's reputation as a moderation variable did not affect to strengthening or weakening the effect between profitability and bond rating.
\end{abstract}

Key words : bond rating, profitability, auditor's reputation and banking.

\section{Pengaruh Leverage, Likuiditas, Profitabilitas, Coverage, Pertumbuhan, dan Ukuran Perusahaan Dengan Reputasi Auditor sebagai Moderating Untuk Peringkat Obligasi dari Badan Perbankan}

\begin{abstract}
Abstrak
Penelitian ini bertujuan untuk mengetahui pengaruh leverage, likuiditas, profitabilitas, coverage, dan ukuran perusahaan dengan reputasi auditor sebagai moderating untuk peringkat obligasi dari perusahaan perbankan yang terdaftar di Bursa Efek Indonesia (BEI) dan dinilai oleh PT Pefindo periode 2004-2013. dalam penelitian ini sampel yang 176 obligasi yang diterbitkan oleh perusahaan perbankan. Teknik pengambilan sampel menggunakan metode purposive sampling, sedangkan metode analisis yang digunakan analisis regresi logistik. Penelitian ini menunjukkan bahwa profitabilitas, pertumbuhan, dan ukuran perusahaan berpengaruh pada rating obligasi. Di lain pihak, leverage, likuiditas, dan cakupan tidak berpengaruh pada peringkat obligasi. Sementara reputasi auditor sebagai variabel moderasi tidak mempengaruhi untuk memperkuat atau melemahkan pengaruh antara profitabilitas dan peringkat obligasi.
\end{abstract}

Kata kunci: Peringkat obligasi, Profitabilitas, Reputasi Auditor dan Perbankan. 


\section{INTRODUCTION}

The capital market is a place where the various of long term financial instruments is being sold. A bond becomes the one of investor option in investing and more interesting for investors. At the end of forth quarter 2013, bond market recorded the second fastest growth in East Asia (Ramadhani, 2014).

An investor who wants to invest through bonds, besides pay attention to the owned funds, an investor must pay attention to the bond rating too. In Indonesia, a few of rating agencies do the bond rating and the one of them is PT Pemeringkat Efek Indonesia (PEFINDO).

The bond rating can help the investor to know the quality of a bond. However there are some event which led to emergence of doubts about the accuracy of bond rating. In 2004, Bank Global's bond was rated A- which didn't appropriate with the bank's status which under the particular supervision by Central Banking (Bank Indonesia) (Hukum Online, 2007). According to Chan et al in Sunarjanto and Tulasi (2013), the one reason why the bond rating is refraction because the rating agencies do not monitor the firm's performance every day. The bond rating also does not give the details explanation about the factors which affect to bond rating's determination.

That event encourages researchers to investigate about bond rating's determination. Furthermore, Several previous studies tried to investigate about the factors that affect the determination of a firm's bond rating, which include leverage, liquidity, profitability, coverage, growth, and firm size. Some of these studies showed different results, where there are some researchers that states if these factors affect the bond ratings and on the contrary. Besides to these five factors there are also other factors that are believed to strengthen the relationship between profitability and bond ratings, namely the auditor's reputation.

Based on the differences in the results of previous studies the researchers wanted to reexamine the effect of leverage, liquidity, profitability, coverage, growth and firm size with auditor's reputation as a moderating to bond ratings of banking firm which listed on BEI and rated by PEFINDO period 2004-2013.

\section{LITERATURE REVIEW}

\section{Signaling Theory}

Signaling theory explains the reason that a firm has a stimulation to give information to the external parties, namely investor and creditor (Dali et al., 2015). The use of signaling theory would be expected that the management of a firm give a signal like information about the bond's quality that could potentially fail to pay or not through bond rating.

\section{Bond Rating}

The level of corporate bond issuer's ability to pay the liabilities, known as bond ratings. A bond rating provided by a rating agency and the one of the rating agency in Indonesia is PT PEFINDO. Bond rating is used by the investors to see the firm's capability to pay its liabilities. Bond rating can be used to see the possibility that the firm will be default or not. Bond rating can decrease the risk when the investor wants to invest in bond. Here are the definition of bond ratings by PEFINDO.

Table 1 Bond Rating based on PEFINDO

\begin{tabular}{cl}
\hline RATING & \multicolumn{1}{c}{ DESCRIPTION } \\
\hline AAA & $\begin{array}{l}\text { A debt security rated which has the highest rating. The obligor's } \\
\text { capacity to meet its long-term financial commitments on the } \\
\text { debt security, relative to other Indonesian obligors, is superior. }\end{array}$
\end{tabular}

AA

A debt security rated which differs from the highest rated debt only to a small degree. The obligor's capacity to meet its longterm financial commitments on the debt security, relative to other Indonesian obligors, is very strong.

A debt security rated which indicates that the obligor's capacity to meet its long-term financial commitments on the debt security, relative to other Indonesian obligors, is strong, however, the debt security is somewhat more susceptible to adverse effects of changes in circumstances and economic conditions than higher-rated debt.

A debt security rated which denotes adequate protection parameters relative to other Indonesian debt securities. However, adverse economic conditions or changing circumstances are more likely to lead to a weakened capacity on the part of the obligor to its long-term financial commitments on the debt security.
A debt security rated which denotes somewhat weak protection parameters relative to other Indonesian debt securities. The obligor's capacity to meet its long-term financial commitments on the debt security is susceptible to major ongoing uncertainties or exposure to adverse business, financial, or economic conditions, which could result in an inadequate capacity of the obligor to meet its financial commitments on the debt security. 
Continue of Table 1 Bond Rating based on PEFINDO

\begin{tabular}{cl}
\hline RATING & \multicolumn{1}{c}{ DESCRIPTION } \\
\hline & $\begin{array}{l}\text { A debt security rated which denotes weak protection } \\
\text { parameters relative to other Indonesian debt securities. } \\
\text { Although the obligor currently still has the capacity to meet } \\
\text { Bts long-term financial commitments on the debt security, any } \\
\text { adverse business, financial, or economic conditions would } \\
\text { likely impair the capacity or willingness of the obligor to meet } \\
\text { its long-term financial commitments on the debt security. }\end{array}$ \\
& $\begin{array}{l}\text { A debt security rated which currently vulnerable to non- } \\
\text { payment, and is dependent upon favorable business and } \\
\text { financial conditions for the obligor to meet its long-term }\end{array}$ \\
& financial commitments on the debt security. \\
& A debt security is rated D when it is in payment default, or \\
default of a rated obligation occurs automatically upon the first \\
occurance of non-payment of the obligation. An exception is \\
warranted when a payment missed on the due date is made \\
within the grace period, or whenever such a non-payment is \\
subject to a bona fide commercial dispute.
\end{tabular}

Source: PEFINDO, 2014.

\section{Leverage}

Leverage is used to measure the extent of the firm's assets are financed by debt (Kasmir, 2012:113). If the financing activity of the firm is used greater debt than its owned capital, then the firm would be said to be unhealthy and easily bankrupt. Leverage ratios measured by debt to equity ratio (DER), debt service ratio (the ratio of debt repayment), the ratio of debt on assets (DAR).

\section{Liquidity}

Liquidity ratio illustrates the firm's ability to complete the short term liabilities (Harahap, 2013:301). Liquidity ratios are current ratio, quick ratio, ratio of cash on current assets, the ratio of cash on current debt, the ratio of current assets and total assets, and the ratio of current assets and total debt.

\section{Profitability}

Profitability ratio illustrates the firm's ability to get some profit through all the capability and resources such as sales activities, cash, capital, and etc (Harahap, 2013:304). Profitability ratios measured by net profit margin, return on asset (ROA), and etc.

\section{Coverage}

Coverage ratio measures the firm's income to the fixed cost which owned by the firm. A Ratio that used is time interest earned ratio (TIER), a ratio that measures the firm's ability to cover interest liabilities with the firm's operational results. Coverage ratio which low indicates that the firm's ability to cover interest liabilities is low and so on contrary (Widiyastuti et al., 2014).

\section{Growth}

Growth ratio is a ratio which illustrates the firm's ability to maintain its economic position in the midst of economic growth and the bussiness sector (Kasmir, 2012:114-115). A growth analysis involve the analysis of sales growth, net income, and etc.

\section{Firm Size}

Firm size is a measure that shows the size of the firm. According to Miswanto and Husnan (in Almilia \& Devi, 2007), firm size can be measured by total asset, sales, or the equity. With the firm size, the investor is able to know the firm's ability to pay the bond interest periodically and pay the principal which can increase the bond rating.

\section{Auditor's Reputation}

A public accounting firm is a business entity that has obtained the permission from the minister as a conduit for public accountant in providing services (Thamida \& Lukman, 2013). The role of external auditors is provided an independent and a professional assessment on the reliability and fairness of the firm's financialstatement presentation. Theexternalauditors can be a mechanism to control the management in order to present the financial information reliably and free from fraudulent accounting practices. The external auditors which included in the members of big four are Price water house Coopers, Deloite Touce \& Tomatsu, Ernst \& Young, and KPMG (Klynveld, Peat, Marwick, Goerdeler).

\section{Leverage and Bond Rating}

Kamstra et al., (2001) revealed that leverage is affect to the bond rating. According to Burton et al., (in Magreta \& Nurmayanti, 2009), if the leverage become higher, then the firm's failure risk become higher too and if the leverage is lower, then the usage of debt to finance the firm's activities is lower.

At least, a firm has a debt proposition which smaller than the amount of owned capital. A smaller amount of liabilities that can be means if the firm is able to pay all its liabilities only with the owned capital so that the firm's default risks become lower. The lower of the default risk, then the bond rating is getting better. 


\section{Liquidity and Bond Rating}

Almilia and Devi (2007), and Susilowati and Sumarto (2010) revealed that liquidity is affect to the bond rating. According to Arifin (in Susilowati \& Sumarto, 2010), the firm's ability to pay its short term liabilities is indicated that firm in liquid condition and indirectly affect to the repay of their long term liabilities which better such as a pay of the bond and the deafult risk become lower. Therefore, the high level of liquidity is affect to the better bond rating.

\section{Profitability and Bond Rating}

Kamstra et al., (2001), Kim and Gu (2004), Magreta and Nurmayanti (2009), Amalia (2012), Melani and Kananlua (2013), Septyawanti (2013), and Sunarjanto and Tulasi (2013) revealed that profitability is affect to the bond rating. If the firm's income become higher, then the firm's ability to pay all its liabilities become higher so the deafult risk become lower and the bond rating getting better too.

\section{Coverage and Bond Rating}

Kim and Gu (2004) revealed that coverage is affect to the bond rating. The firm's quality will be reduce if the firm's ability to pay its liabilities, like bond interest with income is low. The low ability to pay the bond interest is inflict to the bond rating that given is low or decline.

\section{Growth and Bond Rating}

Almilia and Devi (2007), and Sejati (2010) revealed that growth is affect to the bond rating. According to Burton et al.,(in Sejati, 2010), states that the positive growth in the annual surplus can indicate a various of financial conditions. A bond Issuers firm which have high growth from year to year will have greater possibility to obtaining a good bond ratings than the bond issuers firm which have a low growth.

\section{Firm Size and Bond Rating}

Kamstra et al., (2001), Kim and Gu (2004), and Melani and Kananlua (2013) revealed that firm size is affect to the bond rating, where a bigger firm size, then the firm's ability to pay its liabilities become higher so the default risk become lower. The low default risk, then the bond rating which obtained is higher too.

\section{Auditor Reputation, Profitability, and Bond Rating} According to Purnomo and Pratiwi (2009), financial statements are used as tools to look at the earning power of the firm. Financial statements which audited by the auditor with a better auditor's reputation indicates that the audited financial statements is getting better, where the value or numbers in the financial statements would be credible that then can strengthen the effect of the one of factor namely profitability to the bond rating.

A firm with a high profitability is considered able to pay all its liabilities and it can be trusted. So the firm's default risk (failure to pay) is getting lower and the bond rating is getting better. Therefore auditor's reputation is considered as a moderating which can strengthen or weaken the effect between profitability and bond rating.

\section{Hypothesis}

A research hypothesis is a temporary assumption which still to be verified. Based on the theory and the previous studies then the hypothesis that applied in this study are as below:

$\mathrm{H}_{1}$ = Leverage, liquidity, profitability, coverage, growth, and firm size affect the bond rating of banking firm.

$\mathrm{H}_{2}=$ Auditor's reputation affects the effect of profitability to the bond rating of banking firm.

\section{METHOD}

This research is a quantitative descriptive research. The data sources which used in this research is a secondary data. Data in this research is obtained from PT Pefindo website, Indonesia Bond Market Directory, Indonesia Stock Exchange (BEI) and the annual financial statements which is issued by each firm.

Population in this research is the bonds that issued by banking firms which listed in BEl period 20042013.The sample selection using purposive sampling method so that obtain sample of 176 bonds, which issued by 11 banking firms.

There are three variables that used in this research, namely dependent variable, independent variable, and moderating variable. The dependent variable in this research is bond rating which measured using nominal scale with value 1 for bonds that are included 
in the high investment grade( $A A A, A A, A)$ and a value 0 for bonds that are included in the low investment grade (BBB).

The independent variables in this research are the factors which suspected to affect the bond ratings, namely the first, the leverage ( $x \_1$ ). Leverage ratio illustrates the firm's ability to pay long-term liabilities if the firm is liquidated (Harahap, 2013:303). Leverage in this research is proxied by debt to equity ratio (DER).

$$
\mathrm{DER}=\frac{\text { Total Liabilities }}{\text { Total Equity }}
$$

Second, liquidity $\left(x_{2}\right)$. The liquidity ratio illustrates the firm's ability to settle its short-term liabilities (Harahap, 2013:301). Liquidity in this research is proxied by the current ratio.

\section{Current Ratio $=\frac{\text { Current Asset }}{\text { Current Liabilities }}$}

Third, profitability $\left(\mathrm{x}_{3}\right)$. Profitability ratio illustrates the firm's ability to get a profit through all the capabilities and existing sources such as sales activities, cash, capital, and so on (Harahap, 2013:304). A proxy for profitability in this research is net profit margin (NPM).

$$
\text { NPM }=\frac{\text { Net Income }}{\text { Operating Income }}
$$

Fourth, coverage $\left(x_{4}\right)$. A low coverage ratio indicates that the firm's ability to cover interest expense is low and so on contrary (Widiyastuti et al., 2014). Coverage in this research is proxied through time interest earned ratio.

$$
\text { TIER }=\frac{\text { EBIT }}{\text { Interest Expense }}
$$

Fifth, growth $\left(x_{5}\right)$. Firm that have a good growth from year to year will have a greater possibility in obtaining a better bond ratings. Growth in this research is proxied through the book to market ratio.
Book to Market Ratio $=\frac{\text { Market Value }}{\text { Book Value }}$

Sixth, firm size (x_6 ). Firm size is a measure that shows the size of the firm and the investor can find out the firm's ability to pay bond interest periodically and repay the bonds principal that can improve bond ratings. Firm size in this research is proxied by the total assets which owned by each firm.

Firm Size $=\log$ total asset

Moderating variable in this research is a auditor's reputation that measured using a nominal scale with give a value 1 if the bond is issued by the publisher which audited by big 4 auditors and give a value 0 if the bond is issued by the publisher which audited by non-big 4 auditors.

The data collection technique in this research is through documentation or literature searches. The data are obtained through the firm's financial statements and bond rating which issued by PT Pefindo.

The data analysis technique used is logistic regression. The data analysis is divided into two phase, namely the analysis of the effect of leverage, liquidity, profitability, coverage, growth, and firm size to the bond ratings and analysis of the effect of auditor reputation as a moderating between profitability to the bond rating with the regression equation as below.

$\operatorname{Ln} \frac{p}{1-p}=\alpha+\beta_{1} X_{1}+\beta_{2} X_{2}+\beta_{3} X_{3}+\beta_{4} X_{4}+\beta_{5} X_{5}+\beta_{6} X_{6}+e$

Ln $\frac{p}{1-p}=\alpha+\beta_{1} X_{1}+\beta_{2} X_{2}+\beta_{3} X_{3}+\beta_{4} X_{4}+\beta_{5} X_{5}+\beta_{6} X_{6}+\beta_{7} Z+\beta_{8} X_{3} Z+e$

Where:

$\operatorname{Ln} \frac{P}{1-P}=$ Bond Rating

Ln $\frac{P}{1-P}$ investment grade.

Ln $\frac{P}{1-P}$ investment grade.

$\alpha=$ Constanta

$\beta_{1}-6 \quad=$ Regression Coefficient 
X_1 = Leverage

X_2 = Liquidity

X_3 = Profitability

X_4 = Coverage

X_5 = Growth

X_6 = Firm Size

$\mathrm{Z}=$ Auditor's reputation

$\mathrm{X}_{3} \mathrm{Z}=$ Interaction between

profitability and auditor's

reputation

e $=$ Error

\section{RESULT AND DISCUSSION}

\section{STATISTICAL RESULT}

Analysis TheEffect of Leverage, Liquidity, Profitability, Leverage, Growth, and FirmSize To Bond Ratings

The first phase in the analysis is evaluating the overall model (overall model fit) based on the likelihood function and after processing the data through SPSS, the value of $-2 \log L$ is decreased by 27,706 and sig $0.000<0.05$. It indicates that the hypothesized model fit to the data.

The second phase in the analysis is to see the value of Nagelkerke ${ }^{2}$ and after processing the data through SPSS generated the value of Nagelkerke $R^{2}$ is 0.412 , which means if the variability of the dependent variable that can be explained by the variability of the independent variables by $41.2 \%$. The third phase in the analysis is hypothesis testing. Here are the results of data processing in order to see the results of hypothesis testing.

Table 2 Variables in the Equation

\begin{tabular}{lccccccc}
\hline & & B & S.E. & Wald & Df & Sig. & Exp(B) \\
\hline Step 1 & X1 &,- 250 &, 205 & 1,483 & 1 &, 223 &, 779 \\
& X2 &, 142 &, 501 &, 080 & 1 &, 777 & 1,152 \\
& X3 &, 360 &, 103 & 12,303 & 1 &, 000 & 1,433 \\
& X4 &,- 189 & 3,639 &, 003 & 1 &, 959 &, 828 \\
X5 & 2,053 &, 966 & 4,520 & 1 &, 033 & 7,793 \\
& X6 & $-1,107$ &, 495 & 4,988 & 1 &, 026 &, 331 \\
& Constant & 6,830 & 5,327 & 1,644 & 1 &, 200 & 925,174 \\
\hline
\end{tabular}

Source : Output SPSS, 2015.

Based on the table 2 above, the results of hypothesis testing on an analysis the effect of leverage, liquidity, profitability, coverage, growth, and firm size of the bond rating are the first, the variable leverage (X_1) does not affect to the bond ratings with sig $0.223>0.05$. Second, the liquidity variable $\left(X \_2\right)$ does not affect to the bond ratings with sig $0.777>0.05$. Third, profitability variable (X_3) affects to the bond ratings with sig $0.000<0.05$. Fourth, the variable coverage (X_4) does not affect to the bond ratings with sig 0.959>0.05. Fifth, the variable growth (X_5) affects to the bond ratings with sig $0.033<0.05$. Sixth, the variable firm size $\left(X_{-} 6\right)$ affect to the bond ratings with sig $0.026<0.05$.

\section{Analysis The Effect of Auditor's Reputation As A Moderating Between Profitability To Bond Rating}

The first phase in the analysis to evaluate the overall model(overall model fit) based on the likelihood function and after processing the data through SPSS, the value of -2LogLis decreased by 41,678 and sig $0.000<0.05$. It indicates if the hypothesized model fit to the data. The second phase in the analysis is to see the value of NagelkerkeR ${ }^{2}$ and after processing the data through SPSS generated the value of Nagelkerke $\mathrm{R}^{\wedge} 2$ by 0.596 , which means if the variability of the dependent variable can be explained by the variability of independent variables by $59.6 \%$. The third stage in the analysis hypothesis testing. Here are the results of data processing in order to see the results of hypothesis testing.

Table 3 Variables in the Equation

\begin{tabular}{cccccccc}
\hline & & B & S.E. & Wald & Df & Sig. & Exp(B) \\
\hline $\begin{array}{c}\text { Step } \\
1^{\text {a }}\end{array}$ & X1 &,- 112 &, 248 &, 205 & 1 &, 650 &, 894 \\
& X2 &, 100 &, 782 &, 016 & 1 &, 898 & 1,105 \\
& X3 & $-10,524$ & 14210,492 &, 000 & 1 &, 999 &, 000 \\
& X4 & $-3,814$ & 4,058 &, 883 & 1 &, 347 &, 022 \\
& X5 &,- 223 & 1,189 &, 035 & 1 &, 851 &, 800 \\
& X6 &, 695 &, 759 &, 837 & 1 &, 360 & 2,003 \\
& Z(1) & 168,442 & 233052,063 &, 000 & 1 &, 999 & $1,424 \mathrm{E} 73$ \\
& Moderat & 10,725 & 14210,492 &, 000 & 1 &, 999 & 45491,672 \\
& Constant &,- 747 & 6,218 &, 014 & 1 &, 904 &, 474 \\
\hline Source: Output SPSS 2015. & & & & &
\end{tabular}

Based on the table 3 above, the results of hypothesis testing on an analysis the effect of auditor reputation as a moderating between profitability to bond rating is the moderate variable $\left(X_{3} Z\right)$ is not a moderating variable and do not affect the size of the effect 
between the profitability to bond ratings with sig $0.999>0.05$.

\section{The Effect of Leverage To The Bond Rating}

Leverage is used to measure the extent of the firm's assets is financed with debt (Kasmir, 2012:113). Leverage which proxied by a debt to equity ratio (DER) has sig $0.223>0.05$ and its indicates that leverage does not affect the bond ratings. These results are consistent with the results of research conducted by Kim and Gu (2004), Magreta and Nurmayanti (2009), Pandutama (2012), Melani and Kananlua (2013), Sunarjanto and Tulasi (2013), and Widiyastuti et al., (2014).

According to Melani and Kananlua (2013) states that the cause of leverage does not affect the bond rating due to the character of a debt to equity ratio (DER), which is highly dependent on the industry. The firms which become the object of this research is a banking firm. Most of the funds that managed by a banking firm is the funds from the public(third party) which in the accounting system, third party funds are included in liabilities so that lead to the greater amount of debt than the amount of equity which owned by the firm and then the value of DER becomes high. Therefore, it can be said that is not always if the lower value of DER then the firm's ability to pay its liabilities getting better which impact to the bond rating too.

\section{The Effect of Liquidity To The Bond Rating}

Liquidity ratio illustrates the firm's ability to complete the short term liabilities (Harahap, 2013:301). The liquidity which is proxied through the current ratio (CR) has a sig 0.777> 0.05 and indicates that the liquidity variables did not affect the bond ratings. These results are consistent with research conducted by Kim and Gu (2004), Magreta and Nurmayanti (2009), True (2010), Satoto (2011), Amalia (2012), Melani and Kananlua (2013), Septyawanti (2013), Sunarjanto and Tulasi (2013), Thamida and Lukman (2013) and Widiyastuti et al., (2014).

The value of current ratio below 1.0 means that the firm is not healthy and has a negative net working capital (Melani, 2013). The value of a firm's current ratio is affected by the business activities of the firm itself. Banking firm are required to be able to serve the public demand or customer at any time. Based on the regulation of Bank Indonesia at 2004 about the minimum reserve requirement for commercial banks at Bank Indonesia, every banking company is required to have a minimum reserve of $5 \%$ of third party funds in rupiah and $3 \%$ of the deposits of foreign currency so that the amount of that reserves depends how big owned third party funds. Therefore, a low value of a current ratio does not always indicate that the level of liquidity is getting low and so on contrary which then also affect the bond ratings.

\section{The Effect of Profitability To The Bond Rating}

Profitability illustrates the firm's ability to profit through all the capabilities and existing sources such as sales activities, cash, capital, and so on (Harahap, 2013:304). Profitability which proxied through the Net Profit Margin (NPM) has sig $0.000<0.05$ and indicates that profitability affect the bond ratings. These results are consistent with research conducted by Kamstra et al., (2001), Kim and Gu (2004), Magreta and Nurmayanti (2009), Amalia (2012), Melani and Kananlua (2013), Septyawanti (2013), as well as Sunarjanto and Tulasi (2013).

According to Amalia (2012), if a firm is in profit condition, the prediction of the firm survives in a long-term is bigger, including carrying out its liabilities at maturity. The profits can be distributed to the interest coupon payments and the principal of the issued bonds. The higher profits of a firm, so that the firm's ability to pay all its liabilities is higher and lower the firm's defaults risk (failure to pay) which then impact on bond ratings that getting better.

\section{The Effect of Coverage To The Bond Rating}

The low coverage ratio indicates that the firm's ability to cover the interest expenses is low and so on contrary (Widiyastuti et.al., 2014). Coverage which proxied through Time Interest Earned Ratio (TIER) has sig $0.959>0.05$ and indicates that coverage does not affect the bond ratings. These results are consistent with research conducted by Kamstra et al.,(2001), Satoto (2011), as well as Widiyastuti et al.,(2014).

Coverage does not affect the bond rating because there is some restructuring through a decrease in the amount of interest which then impact on the amount of interest which borne by the recipient on the wane and leads to the higher coverage value. So it is not 
JURNAL BISNIS \& MANAJEMEN

ISSN 1412 - 3681

always if high coverage value indicates that the firm can pay its liabilities and get a good bond rating.

\section{The Effect of Growth To The Bond Rating}

A firm with a better growth indicates that the firm has a better prospect of cash flow in the future and the company is considered to have an ability to pay its liabilities properly so that the firm's default risk (failure to pay) is also getting lower and the bond ratings is getting better. Growth which proxied by Book to Market Ratio has sig $0.033<0.05$ and indicates that the growth affect the bond ratings. The research results are consistent with research conducted by Almilia and Devi (2007), and Sejati (2010).

Pottier and Sommer (in Sejati, 2010) stated that the strong business growth is positively related to the rating decision and the ratings which provided by the rater of the bond. If the firm's growth getting better, the firm's ability to pay its liabilities, such as bonds will be getting better and the default risk (failure to pay), will be lower which then impact to the better bond rating.

\section{The Effect of Firm Size To The Bond Rating}

Firm size is a measure that indicates the size of the firm. The bigger firm has a bigger sales, total assets, or equity too and the firm can pay its liabilities properly. Firm size which proxied through the log total assets have sig $0.026<0.05$ and indicates that firm size affect the bond ratings. This result is consistent with research conducted by Kamstra et al., (2001), Kim and Gu (2004), and Melani and Kananlua (2013).

The assets which owned by a firm will be a firm guarantee to pay all its liabilities. However, a large amount of assets does not always indicate that the bond ratings which given also good. If the assets are dominated by assets such as loans which given to the customers who have a high risk enough to be disruption for the firm to pay its liabilities. So that the firm's default risk (failure to pay) become higher and the bond ratings will be lower.

The Effect of Auditor's Reputation as A Moderating Between Profitability To The Bond Rating.

According to Purnomo and Pratiwi (2009), financial statements are used as a tool to look at the earning power of the firm. Financial statements which audited
Jurnal Bisnis \& Manajemen, 2016, Vol. XVII, No. 1, 48-57

by the auditor with better auditor's reputation indicates that the audited financial statements is getting better, where the value or numbers in the financial statements would be credible. The financial statements which audited by the big 4 auditors considered to have a better quality than the financial statements which audited by the non-big 4 auditors.

Auditor's reputation which proxied by giving a value 1 if audited by the big 4 auditors and giving a value 0 if audited by the non big4 auditors have sig $0.999>0.05$, which indicates that the auditor's reputation is not a moderator between profitability and bond ratings.

According to Marisatusholekha (2015) auditor's reputation does not affect the earning quality of a firm. The earning quality of a firm which audited by big 4 auditors is no different with earning quality of a firm which audited by the non-big 4 auditors. This is because the firms that used as a sample are in a competitive industry. So it is not always a firm with the big 4 auditors can guarantee the good earning quality and it cannot guarantee the firm's ability to pay its liabilities such as bonds.

\section{CONCLUSION}

The conclusion that can be provided based on the results of a whole hypothesis testing, namely first, leverage, liquidity, and coverage does not affect the bond ratings of banking firm. Second, profitability, growth, and firm size affect the bond ratings of banking firm.

The future research may use other firms as a sample, adding a variable, a longer period, and should use an ordinal scale to categorizing a bond rating variable and auditor's reputation variable. Investors should look at the level of profitability, growth, and the firm's size in advance before investing in a bond. The firm which have high levels of profitability, growth, and firm's size indicates that the firm has a better bond rating so the default risk (failure to pay) would be inevitable.

\section{REFERENCES}

Almilia, Luciana Spica., \& Vieka Devi. (2007). FaktorFaktor Yang Mempengaruhi Prediksi 
Peringkat Obligasi Pada Perusahaan Manufaktur Yang Terdaftar Di Bursa Efek Jakarta. Proceeding Seminar Nasional Manajemen SMART. Bandung: Universitas Kristen Maranatha.Bulan November.

Amalia, Ninik. (2012). Pemeringkatan Obligasi PT. Pefindo : Berdasarkan Informasi Keuangan. Accounting Analysis Journal. 2 (2) : 139 - 147.

Dali, Ly Chandra., Sautma Ronni, \& Mariana Ing Malelak. (2015). Pengaruh Mekanisme Corporate Governance dan Rasio Keuangan Terhadap Peringkat Obligasi. FINESTA. 3 (1) : 30 - 35.

Harahap, Sofyan Syafri. (2013). Analisis Kritis Atas Laporan Keuangan. Jakarta: PT. Rajagrafindo Persada.

Hukum Online. (2007). Bank Global Digugat Ratusan Miliar Rupiah, (Online), (http://www. hukumonline.com/berita/baca/hol17075/ bank-global-digugat-ratusan-miliarrupiah).

Kamstra, Mark., Peter Kennedy, \& Teck-kin Suan. (2001). Combining Bond Rating Forecasts Using Logit. The Financial Review. 36(2):7596.

Kasmir. (2012). Analisis Laporan Keuangan. Jakarta: PT. Rajagrafindo Persada.

Kim, Hyunjoon., \& Zheng Gu. (2004). Financial Determinants Of Corporate Bond Ratings : An Examination of Hotel And Casino Firm. Journal of Hospitality \&amp: Tourism Research. 28:95-108.

Magreta., \& Poppy Nurmayanti. (2009). Faktor-Faktor yang Mempengaruhi Prediksi Peringkat Obligasi Ditinjau dari Faktor-Faktor Akuntansi dan Non Akuntansi. Jurnal Bisnis dan Akuntansi. 11 (3) : 143 - 154.

Marisatusholekha., \& Eddy Budiono. (2015). Pengaruh Komisaris Independen, Reputasi Kap, Persistensi Laba, Dan Struktur Modal
Terhadap Kualitas Laba (Studi Pada Perusahaan Telekomunikasi Yang Terdaftar Di Bursa Efek Indonesia Tahun 2009-2013). Bina Ekonomi. 19(1):53-70.

Melani, Kingkin Sandra., \& Paulus Sulluk Kananlua. (2013). Analisis Pengaruh Rasio Keuangan Terhadap Peringkat Obligasi Perusahaan Manufaktur Yang Terdaftar di Bursa Efek Indonesia. Management Insight, Jurnal IImiah Manajemen. 8(2):45-56.

Pandutama, Arvian. (2012). Faktor-Faktor Yang Mempengaruhi Prediksi Peringkat Obligasi Pada Perusahaan Manufaktur di BEI. Jurnal IImiah Mahasiswa Akuntansi. 1 (4) : 82 - 87.

Pefindo. (2014). Rating Definition, (Online), (http:// www.pefindo.com).

Purnomo, Budi S., dan Puji Pratiwi. (2009). Pengaruh Earning Power Terhadap Praktek Manajemen Laba (Earning Management). Jurnal Media Ekonomi. 14 (1) : 1 - 13.

Ramadhani, Silvia., (2014). Pasar Obligasi RI Terbesar Kedua di Asia Timur, (online), ( http://economy.okezone.com / $\mathrm{read} / 2014 / 03 / 20 / 20 / 958011 /$ pasarobligasi-ri-terbesar-kedua-di-asia-timur).

Satoto, Shinta Heru. (2011). Analisis Faktor-Faktor Yang Mempengaruhi Bond Rating. Karisma. 5 (1) : 104 - 115.

Sejati, Grace Putri. (2010). Analisis Faktor Akuntansi Dan Non Akuntansi Dalam Memprediksi Peringkat Obligasi Perusahaan Manufaktur. Bisnis \& Birokrasi, Jurnal Ilmu Administrasi dan Organisasi. 17(1):70-78.

Septyawanti, Hilda Indria. (2013). Faktor-Faktor Yang Mempengaruhi Peringkat Obligasi Perusahaan. Accounting Analysis Journal. 2 (3) : 276 - 285.

Sunarjanto, N. Agus., \& Daniel Tulasi. (2013). Kemampuan Rasio Keuangan Dan Corporate Governance Memprediksi Peringkat Obligasi 
JURNAL BISNIS \& MANAJEMEN

ISSN 1412 - 3681

Pada Perusahaan Consumer Goods. Jurnal Keuangan dan Perbankan. 17 (2) : 230-242.

Susilowati, Luky., \& Sumarto. (2010). Memprediksi Tingkat Obligasi Perusahaan Manufaktur Yang Listing Di BEI. Jurnal Mitra Ekonomi dan Manajemen Bisnis. 1 (2) : 163 - 175.

Thamida, Nelly., \& Hendro Lukman. (2013). Analisis Faktor-Faktor yang Mempengaruhi Peringkat Obligasi pada Industri Perbankan
Jurnal Bisnis \& Manajemen, 2016, Vol. XVII, No. 1, 48-57

yang Terdaftar di Bursa Efek Indonesia Periode 2008-2012. Jurnal Akuntansi. XVII (02) : 198 - 211.

Widiyastuti, Tetty., Djumahir, \& Nur Khusniyah. (2014). Faktor-Faktor yang berpengaruh terhadap Peringkat Obligasi (studi pada perusahaan manufaktur yang terdaftar di BEI). Jurnal Aplikasi Manajemen. 12 (2) : $269-278$. 